\title{
Environmental Management of Lake Toba Tourism Area Indonesia
}

\author{
Indra Jaya \\ State Islamic University of North Sumatera, North Sumatera, North Sumatera, Indonesia \\ indrajaya@uinsu.ac.id
}

\begin{abstract}
The objectives of this research was to know empirical information about the environment of Toba Lake tourism area as basis for building an alternative environmental management model. The research had been conducted at Lake Toba situated in North Sumatera. The research employed different steps i.e. survey, literature study, development of a conceptual model, validation of the model, preliminary test, evaluation and model revision, and finalization of the model developed. The results of the research indicated that the management of Lake Toba tourism must be improved and developed on the perspectives of sustainable environment and development
\end{abstract}

Keywords: Lake Toba Tourism area, environmental management

\section{Introduction}

North Sumatera is one of ten leading tourist destinations in Indonesia. The province has 339 tourist attractions spread throughout its 33 municipalities. Until today 120 of them have been promoted and marketed. One attraction that is promoted for its natural beauty is Lake Toba. It is indeed the mainstay tourist attraction of the province. There are 8 regencies having administrative territories around the lake. Each has tourist sites with their respective unique characteristics.

The beauty and affluent natural resources of Lake Toba are magnetic for tourists. As time goes by, the number of population dwelling around the lake keeps increasing, leading to the increase in the use of natural resources. For example, the lake is used as the source for drinking water processing, electricity power plant, and fish farming.

Consequently, the environment has to experience decrease in quality. The natural condition of the lake is susceptible to environmental dangers. The steep topography, erosion-prone type of soil and type-C climate, which is very dry in dry season, are natural factors that make the region is vulnerable to environmental hazards. Exploitative activities that less consider the sustainability of the environment have caused many problems. In general, the problems include: decrease of water quality, damage to water catchment area and threat to biodiversity (source: Strategic Environmental Assessment of Lake Toba Region, Environment Agency of North Sumatera Province, 2011).

Tourism activities that are based on the natural environment of Lake Toba are required to keep protecting it in order to stay clean, attractive, and sustainable so that tourism businesses would also sustainable. In fact, its ecological condition is less preserved. It can be seen in the perspectives of environmental quality and balance. The problems of sanitation, water pollution, soil pollution, air pollution, noise pollution, aesthetic value of environment, vegetation, and waste management are aspects that still need to be tackled seriously.

The development of tourist area is expected to enable people to cultivate local economic potentials and to preserve the environment. However, problems come up when the use of natural resources tends to be exploitative. So, it must be overcome through integrated development of tourist area on basis of biodiversity and natural sustainability. 
Tourism by-products in the form of garbage and waste activities have considerable potential to pollute and reduce the quality of tourist site environment. Such conditions are closely related to various factors including management policies, management of tourist areas, human resources, facilities and funds, natural resources, etc. Therefore, a study is needed to search for and elaborate the substance of environmental management comprehensively in the Lake Toba tourism area in North Sumatra. This paper aims to determine the quality of the environment in the Lake Toba Tourism Area and the factors related to the region. In the next stage, a model for tourism area management that is oriented towards environmental conservation is developed.

\section{Literature Review}

\subsection{Management of Environment}

The concept of environmental management can be explained based on theories of management. According to Terry and Rue (2001:1), management is a process or framework involving guidance or direction of a group of people to their organization's common goal. The objective of environmental management in Indonesia according to Sugandhy (1999) are: (1) achievement of harmony between humans and environment for building the people as complete humans; (2) controlled and sensible use of resources; (3) realization of Indonesian people as environmentalists; (4) implementation of environmentally aware development for the sake of present and future generations; and (5) protection of the state from the impacts of activities harming and polluting environment. The aspects and functions of management include planning, organizing, directing and controlling.

Planning is an action of setting what will be done, how to do it, what must be done, and who will do it. This action serves as a model of reasonable decision making in selecting and determining action to accomplish a goal. Planning in the context of environmental management is highly needed as a guideline for developing a tourist area. In doing so, the use of natural resources must be planned reasonably, optimally, and responsibly in accordance with the carrying capacity. In addition, it must also consider the balance of environment and biodiversity in order to realize sustainable development (Lundlberg, 1997:16). Sumarwoto (1994:61) grouped activities of environmental management into four levels, namely (1) regular environmental management, (2) preliminary planning of environmental management of a region that becomes the basis and guideline for development planning, (3) environmental management planning based on the estimated impacts of the project plan, and (4) environmental management planning for repairing damage. The third and fourth are the ones that lately have received a lot of attention in the environmental management.

The next step is implementation or mobilization. It is the work of integrating the efforts of members of a group in such a way as that with the completion of tasks assigned to them, they fulfill their individual and group goals (Terry, 2001:181). Implementation in the context of environmental management is to encourage individuals or groups of individuals to carry out activities or do works efficiently and effectively to maintain the sustainability of environment. The measures that can be taken are among others explaining the reasoning of the significance and importance of environmental management, recognizing the efforts and individuals involved in the activities of environmental management, communicating the goals of activities of environmental management, carrying out meeting to stimulate people within the process, and overcoming any conflict and reducing any possible risks in the process. 
The evaluation of environmental management of a tourist area is closely related to these components i.e. the tourist area, facilities and infrastructure, process of policy management, policy output, inter-institution cooperation and the impacts of environmental management. The valuation in this study included activities to gather information about management, tourist area management that involves planning, organizing, implementation, evaluation and development. It is very important to know whether the planning has been successfully realized.

The next step is development. It functions as improvement in term of quality to have better programs. Development of tourist area must be based on national regulations and international agreements. All national regulations and international agreements become the foundations of national eco-tourism development. Local tourism development takes its basis on the local regulations and perceptions and preferences of the people as a realization of new paradigm that empowers local communities. The goals of tourism development are natural and cultural sustainability, and people's welfare.

According to Cooper (2000:16), "tourism as a temporary movement to destinations outside the normal home and workplace, activities undertaken during the stay and facilities created to cater for the needs of tourist'. Tourist area is a region of certain size in which facilities are built to satisfy the needs of tourists. Tourism in a directed environment is everything related to tourism in a constructed environment, including the objects and attraction as well as businesses related to it without harming the environment. The substance of tourism in ecotourism "Ecotourism is environmentally responsible travel and visitation to relatively undisturbed natural areas, in preset order to enjoy and appreciate nature (and any accompanying cultural features-both past and present) that promotes conservation, has low negative visitor impact, and provides for beneficially active socio-economic involvement of local population" (Ceballos-Lascurain, 1996:1).

Based on explanation above, it can be concluded that people dwelling in the ecotourism area of Lake Toba are expected to have capacity to hold the responsibility for conserving the environment with a perspective that is aware of social welfare and sustainable ecosystem for the next generations.

\subsection{Model of Environmental Management of Tourist Area}

Environmental management in the policy of tourism development is an important condition for providing service to tourists. Tourism development and environmental management are two things complementary to each other to create attraction for tourists. Therefore, it needs professional management, which consist of these following elements:1) Specific marketing for the tourist destination. Marketing strategies are very important to reach and attract visitors. They are expected to be sources of information for other visitors so that they can help conserve the environment and develop local communities; 2) Skills and services for visitors. Tourism services are experiences and education about the environment or the new places they visit. The satisfaction of visitors can be reached with various patient and effective services; 3) Participation of local people in guiding visitors about the tourist destination. Local people will get incentives and benefits from environmental conservation if they are involved in ecotourism services; 4) Government's policies in protecting environmental and cultural assets. Policies on management of area, combined with economic instrument, will prevent market mechanism from operating in the ecotourism areas; 5) Development of local communities' competence and their environments are a whole unit of 
tourism. Their potentials and participation need to be enhanced in order to get incentives and they are motivated to protect their environment (Nugroho, 2004:1).

The model of environmental management in the directed tourism area begins with the concept of development as an effort to expand or advance an activity. The model can be used as a guideline for designing environmental management activities including sustainable tourism areas. National Geographic Online in The Global Development Research Center (2002) defines sustainable tourism as follows:1) tourism that provides information. Tourists not only learn about the areas visited but also about how to support the continuity of the character of the areas visited during their trips; 2) tourism that supports integrity (integrity) of the destination. Visitors understand and look for businesses that can emphasize the character of the destinations in term of their architecture, cuisine, heritage, aesthetics and ecology; 3) tourism that benefits the local communities. Tourism entrepreneurs do their best to hire and train local people, buy local supplies, and use services generated from local communities; 4) tourism that protects natural resources. Tourists realize and strive to minimize pollution, energy consumption, and use of water, chemicals and lighting at night; 5) tourism that respects local culture and tradition. Tourists learn and see local procedures including using a few polite words from the local language. Local people learn how to deal with tourist expectations that might be different from the expectations they have; 6) tourism does not abuse products. Stakeholders anticipate the pressure of tourism development and apply management boundaries and techniques to prevent tourist site destruction syndromes. Stakeholders work together to protect natural habitats, cultural heritage, interesting sights and local culture; 7) tourism emphasizes quality, not quantity. People consider tourism successful not only from the number of visitors but from the length of their stay, the amount of money they spend, and the quality of experience they gain; 8) tourism is an impressive trip. Tourists tell their satisfaction and excitement to their friends and relatives so that they are interested also in getting the same things.

A model that can be developed for environmental management includes reasoning, which underlies and exposes the advantages and reasons, which are added with supporting evidence. One of operational models developed by Knowles (1980) consists of five stages: (1) problem definition, (2) information gathering, (3) identification of problem solving alternatives, (4) decision making, and (5) implementation of actions. According to Johansson there are four categories of models, namely: (1) cognitive models (Human Concepts), (2) normative models (purpose oriented), (3) descriptive models (behavior oriented), and (4) functional models (action and control oriented) (Danim, 1998: 22-23).

Based on the proposed model category, the model developed in this study refers to the conceptual model that constitutes a representation of several models for designing environmental management models that can describe techniques of environmental management. Thus, the model in this study is intended as a model of environmental management for tourist areas of Lake Toba. Basically, the model refers to the portrait of an ideal living environment so that the product of this model is a blue print of the environment itself. On the other hand, the model of environmental management for Lake Toba tourism area always refers to how to develop methods of managing nature so that the products can be of quality and in accordance with the objectives of environmental management itself. It can help distinguish between the essential and non-essential things from problem situations. It is also an artificial tool to compile imaginatively and interpret experiences about problem situations. 


\section{Methodology}

This study aimed to create a model for developing an environmental management for Lake Toba tourism. It was carried out with a Research and Development approach through several steps as follows: First, the survey was conducted in a qualitative and descriptive form to get a general overview of the Lake Toba Tourism Area. Second, the literature study was done to find theories and concepts relating to the environment, environmental management, and environmental management models. The results of the study were used as the materials for hypothetical modeling. Third, the environmental management models was prepared based on the results of the survey and literature study. The resulting model was a conceptual model or hypothetical model that needs to be tested further. Fourth, the model was confirmed by expert to produce a useable model before being tested empirically and validated by practitioners. Fifth, limited trials were done to determine the feasibility of the conceptual model that has been compiled through the assessment of the model's implementation by the users, namely the elements of local authorities and executors of environmental management in the Lake Toba Tourism Area. The test results were used as the materials for revising the model to be more applicable. Sixth, the model was evaluated and developed through an evaluative research. The evaluation was directed at making judgments about the values or benefits of programs, processes and results. The development was directed at perfecting the program and its implementation to suit the needs in the field. Seventh, the definitive model of environmental management of the Lake Toba Tourism Area was prepared for implementation on the basis of evaluation results in terms of content, language, systematics and implementation.



Figure 1. Stages of the research process

\section{Discussion}

Based on the results of the theoretical/conceptual model validation by experts as well as by practitioners as stated above, further development of environmental management models for the Lake Toba Tourism Area was carried out. The development was based on the notes and comments of experts and practitioners so that the model that was produced from this study would be more applicable in accordance with their suggestions. The model developed was tested empirically through field evaluations by practitioners. The evaluation results were the final findings of this study. Following is the content framework of the theoretical/conceptual model that has been developed based on the results of validation by both experts and practitioners of the Lake Toba Tourism Management. 


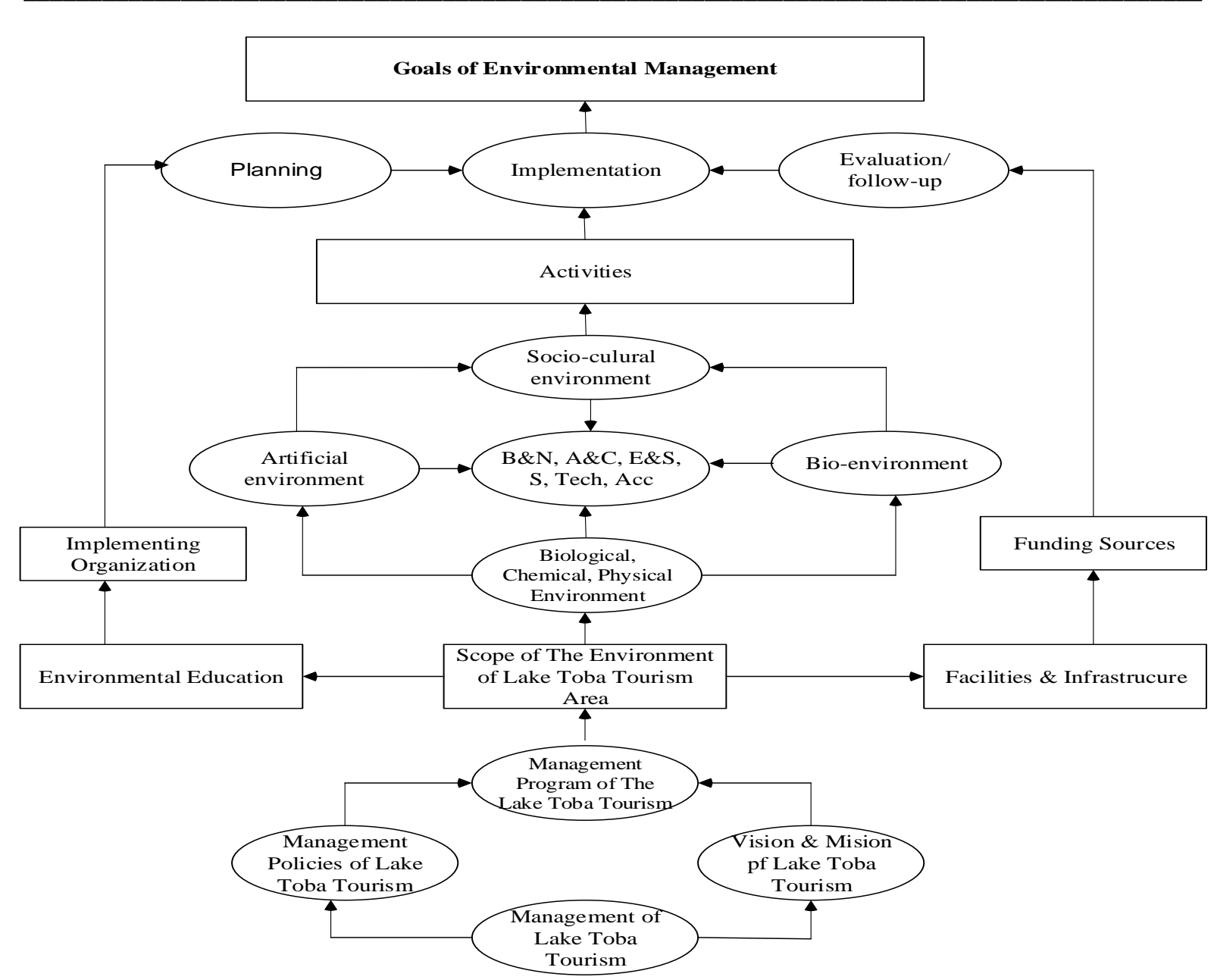

Note: B \& $\mathrm{N}=$ Beach \& Nature; A \& $\mathrm{C}=$ Art \& Culture; E \& S = Education \& Science; $\mathrm{S}=$ Sport Tech $=$ Technology; Acc $=$ Accommodation

Figure 2: The Model of Environmental Management of Lake Toba Tourism Area

\subsection{Evaluation of the Model of Environmental Management of Lake Toba Tourism Area}

The testing of the conceptual model above was evaluated through an evaluative research. Evaluation was carried out by operational managers who carried out daily management of the Lake Toba Tourism Area. Evaluation was carried out using instruments developed by the researchers. These instruments revealed the model's contents, systematics, language, implementation in the field and benefits for the operators. The instruments were created in the form of scaled questionnaires, ranging from 1 (one) as the lowest to 4 (four) as the highest. There were 40 respondents selected purposively. They were those directly participating in the execution of environmental management in the Lake Toba Tourism Area. The data resulted from the evaluation were analyzed using descriptive statistics.

From the 20-question instrument with the lowest score of 1 and highest of 4, which revealed the language, systematics, content, implementation and constraints manager may face in the field was obtained the theoretical minimum score of 40 and a maximum score of 80. While the empirical score or real score was obtained at least 47 and at the maximum 74 
with an average of 65.25 , median 68 , mode 71 standard deviation 7.72 and variance 59.62 . If the average value was compared to the theoretical maximum score of 80 , the effectiveness of this model reached $81.56 \%$. Based on the position of variance values between the minimum and average values, it depicted that the opinions of most respondents said that they were already good, correct, understandable and easy to implement.

The assessment of the accuracy of the language used was conducted with 2 questions so that theoretically the lowest score was 1 and the highest score was 8 . Based on the evaluation data were obtained the lowest score 4; highest score 8; average of 6.77; median 7.0; mode 8; standard deviation 1.3. The data above shows the language used is considered good, meaning that the language and terms used in academic texts/ model can be understood by the managers because they reached the score of $83.75 \%$ of the maximum score.

Evaluation of the content systematics of the model was conducted with 2 questions so that theoretically the minimum score was 1 and the maximum score was 8 . Based on the data from the results, the lowest score was 4 , highest score 8 , average 6.2, median 7.0, mode 8 , and standard deviation 1.3. The score above shows that the content systematics of the manuscript is considered applicable or good because it reached the score of $85 \%$ of the maximum score. This means the participants' assessment of the systematic content of the text was accurate and logical.

Evaluation of the contents of the text was conducted with a 7-question questionnaire so that theoretically the minimum score was 1 and the maximum score was 28 . Based on the evaluation results, the lowest score was 14 , maximum score 28 , average scare 23.72 , media 24.5, mode 28, and standard deviation 4.45. The scores showed that the text content could be accepted or was suitable with the respondents' opinions because they reached a score of $84.71 \%$ of the maximum score. This means the participants' evaluation of the text contents was good/correct/appropriate.

The evaluation of the implementation of the model in the field was conducted with 7 questions so that theoretically the lowest score was 1 and the maximum was 28 . Based on the results of the evaluation, the lowest score was 20 , highest score 28 , average 22.35 , median 22, mode 22 and standard deviation 1.73. The scores showed that according to respondents the model of environmental management of Lake Toba Tourism Area can be implemented in the field because it reached a score of $79.82 \%$ of the maximum score. This means that the model can be implemented by managers in the field.

The evaluation of the obstacle possible faced in implementing the model was conducted with 2 question so that theoretically the lowest score was 1 and the maximum was 8 . Based on the evaluation results, the lowest score was 4 , highest 8 , average 5.57 , median 6 , mode 6 , and standard deviation 0.9. This indicated that the implementation of the model did not go through many obstacles and if there were obstacles, the operators of Lake Toba tourism sites had been able to overcome them. From these evaluation results, it could be concluded that the text of the environmental management model for the Lake Toba tourism formulated through this study was considered good and effective enough so that it can be implemented in the field. The obstacle faced in the implementation could still be overcome by the operators in the field. These data were strengthen with notes and comments from almost all respondents who stated that the model texts were appropriate, good and adequate for field implementation.

The development of environmental management model for Lake Toba tourism can be internalized and socialized as an example for developing similar model for other tourist sites 
having similar characteristics with Lake Toba. The model can be considered and used as comparison with other environmental management of other tourist regions in Indonesia.

The follow up of the results of this study is how the findings of this study can be disseminated to places of similar spatial management with the region of Lake Toba tourism. In order to anticipate the progress and acceleration of development in North Sumatera, the priority and main agenda of the local government must be a serious planning for the development of Lake Toba tourism with sustainable development approach.

\section{Conclusion}

Below are tourist areas around Lake Toba situated in several regencies; 1) In North Tapanuli Regency, there are: Sibandang Island, Rura Silindung, Hot Water Spring, Air Soda Water Pool, and Salib Kasih; 2) In Samosir Regency, there are: Pusuk Buhit, Batu Persidangan, Tomok, Ambarita Village, Tutuk Village, Lake Sidihoni, and Pangururan Hot Water Spring; 3) In Simalungun Regency, there are: Parapat; Tigaras; Pematang Purba; Simalungun; Traditional House; Haranggaol; Batu Gantung; Tanjung unta; 4) In Dairi Regency, there are: Sidiangkat Summit Panorama; Aek Nauli Panorama; Lake Lau Kawar; Iman Sitinjo Park, Lae Pandaroh Waterfall; 5) Toba Samosir Regency, there are: Balige, Luman Silintong Beach, Sampuran Waterfall, Batak Museum; 6) Humbang Hasundutan Regency, there are: Sisingmangaraja Palace, Pertenunan Ibunda Raja Sim XII Cave; 7) Karo Regency, there are: Sipiso-piso Waterfall, Gundaling Hill, Sikulikap Waterfall, Mount Sibayak, Mount Sinabung, Tongging, Simalem Park. It must be admitted that in some areas pollutions in the water, soil and air still occur, especially along the coast of Lake Toba although the contaminations are still within accepted threshold that is not dangerous.

The environmental management in Lake Toba tourism areas must be improved and developed in accordance with the recent demand, and environmental conservation supports a sustainable development. Although what have been done in the management of Lake Toba tourism are already good enough, the efforts of improving the quality of the environment in both its biological and socio-cultural aspects need to be intensified in accordance with the environmental management policies.

The environmental management model for Lake Toba tourism developed through this study rests on current dynamic environmental management that always prioritizes the quality of environmental conservation enriched with empirical facts and theoretical studies in order to keep environment sustainable. The framework for the content of the environmental management model for the Lake Toba tourism found in this study consists of seven components, namely: (1) Reasoning, (2) Management vision and mission, (3) Management policy, (4) Management goals and objectives , (5) Management program, (6) Management scope, (7) Environmental Education, (8) Resources and funds needed, (9) Implementing organizations (10) Management stages, (11) Planning, (12 ) Implementation, (13) Evaluation and follow-up, (14) Closing.

There are a number of factors that must be considered in order to be able to implement the model. One of which is the managers' knowledge about environment including the basic concept of social and environmental management of tourism areas around the lake. To realize this expectation, it is necessary to carry out educational programs in connection with environmental management for local communities, environmental agencies of the North Sumatera government and then to improve the facilities and infrastructure that becomes the 
charms and attractions of Lake Toba tourism. Sufficient funding is used for the effective operation of environmental management. Visitors are expected to understand the meaning of environmental management. In addition, local communities need to have motivation to participate in the efforts of conserving their environment. If all components appreciate and participate in the implementation of environmental management for Lake Toba tourism areas, they definitely will gain optimum results.

\section{References}

Cater, E. \& Lowman, G. (1994). Ecotourism in the third world: Problems and prospects for sustainability. New York: John Wiley \& Sons Ltd.

Cooper, O., Fletcher, J., Gilbert, D., \& Wanhill, S. (1994). Tourism: Principles \& Practice. Malaysia: Longman Group.

Danim, S. (1998). Integrated Processing Model of Regional Education Personnel Education System. Study of the Functions and Effectiveness of Educational Personnel Education Models in Bengkulu Province. Dissertation. Institut Keguruan Ilmu Pendidikan, Bandung, Indonesia.

Fandeli, C. (2000).Ecotourism business. Faculty of forestry. Universitas Gadjah Mada Yogyakarta with Pustaka Pelajar and Natural Resource Conservation Unit.

Jamieson, W., \& Noble, A. (2000). A Manual for Community Tourism Destination Management. Canadian Universities Consortium Urban Environmental Management Project Training and Technology Transfer Program. Canada

Knowless, M. S. (1980). The Modern Practice of Adult Education: From Pedagogy to Andragogy. Chicago: Follet Publishing Company.

Lascurain, C. (1996). Tourism, ecotourism and protected areas. The state of nature-based tourism around the world and gudeliness for its development. IUCN.

Lundlberg, D.E., Stavenga, M.H., \& Krishnamoorthy. (1997). Tourism Economy. Jakarta: Gramedia Pustaka Utama.

Mondy, R. W., \& Shane R. P. (1993). Management: Concepts, practices, and skills. USA: Allyn and Bacon.

Nugroho, I. (2004). Ecotourism. Malang: UWM.

Prosser, R. (1994). Societal change and the growth in alternative tourism. New York: John Wiley \& Sons.

Robbins, S.P. (1988). Organizational behavior: Concept, controversies and pplications. New Jersey: Prentice- Hall International.

Soemarwoto, O. (2016). Ecology, Environment and Development. Jakarta: Djambatan.

Stoner J.A., \& Freeman, R.E. (1992). Management. Eaglewood Cliffs.

Sudjana, D. (2000). Outside School Education Insights into the History of the Development of Philosophy \& Supporting Theories of Principles. Bandung: Falah Production. (2000). Management of Out-of-School Education Programs and HR Development. Bandung: Falah Production.

(1993). Methods and Participatory Learning Techniques in Out of School Education. Bandung: Nusantara Press.

Sugandhy, A. (1999). Spatial Planning in Environmental Management. Jakarta: Gramedia Pustaka Utama Ltd. 
Terry, G.R., Rue, L.W., \& Ticoalu, G.A. (2001). Fundamentals of management. Translated by Ticoalu, G.A. Jakarta: Bumi Aksara.

The Global Development Research Center. (2002). Sustainable Tourism Info-Sheets. http:// gdrc.org/uem/ecotour/whayis-sustour.html

Wight, P. (1994). Environmentally Responsible Marketing of Tourism. New York: John Wiley \& Sons Ltd.

Wood, M. E. (2002). Ecotourism: Principles, practices and policies for sustainability. UNEP. The International Ecotourism Society. http://www.unepie.org/tourism/library/ecotourism.htm

Yoeti. O, A. (1983). Introduction to tourism. Bandung: Angkasa Publishing Company. 